\title{
Efficacy of regional analgesia techniques in abdominal surgery patients with obesity
}

\author{
S. I. Vorotyntsev ${ }^{1}$, M. B. Hrynovska ${ }^{2}$, M. M. Sofilkanych ${ }^{1}$, 0. V. Zakharchuk ${ }^{1}$
}

${ }^{1}$ Zaporizhzhia State Medical University, Ukraine, ${ }^{2}$ Ivano-Frankivsk National Medical University, Ukraine

The use of regional anesthetic techniques in abdominal surgery is an essential component of the multimodal approach to perioperative analgesia, yet data on their use in obese patients remains limited.

The aim of this study is to determine the effectiveness of the epidural analgesia (EA) and the transversus abdominis plane block (TAP-block) in laparoscopic obese patients, as well as to evaluate the possibility of using the rectus sheath block (RSB) as a "rescue" anesthetic technique after laparotomy in obese patients.

Materials and methods. The data on the 102 obese patients operated on esophageal hiatal diaphramgmatic hernia, colon tumor, postoperative ventral hernia, morbid obesity and choledocholithiasis were analyzed. In laparoscopic surgery 20 patients received EA (EA group), 21 patients - TAP-block (TAP group), 21 patients - opioids and non-steroidal anti-inflammatory drugs (NSAIDs) without any regional anesthesia techniques (group TIVA $_{1}$ ). In laparotomic surgery 16 patients received RSB (RSB group) and 24 patients - only opioids and NSAIDs (TIVA ${ }_{2}$ group). After the surgery the following was estimated: the time of extubation, the total dose of opioids, the level of pain according to the 10-point numeric range score (NRS), the incidence of dyspnea using the monitor Utas 300 (Ukraine), the incidence of postoperative nausea and vomiting (PONV), the time of active patient mobilization, and the level of satisfaction with analgetic regimen. For the RSB group, the complexity of the RSB and the mean time to achieve adequate analgesia (pain intensity $\leq 3$ points per NRS) were determined additionally. The statistical analysis was performed using the Statistica for Windows version 6.0 software.

Results. In the EA group, the intraoperative dose of fentanyl was twice lower, and patients were extubated two times faster than in the TAP, TIVA, $R S B$, TIVA 2 groups $(P<0.05)$. At the same time, none of the patients in the EA group required the restoration of neuromuscular conduction with neostigmine $(P<0.05)$. After the surgery, the pain level was $2-3$ times higher in the TIVA, $R S B$, and TIVA groups than in the EA and TAP groups $(P<0.05)$. "Rescue" analgesia in the RSB group was performed from the first attempt in all the patients in 5-10 minutes and provided an adequate effect in $3(2-4)$ min. The complexity level of RSB was defined as "easy" in $12(75 \%)$ patients, as "average" in $4(25 \%)$ patients $(P<0.05)$. The incidence of dyspnea and opioid doses after surgery in the EA, TAP and RSB groups of patients were 2 times lower, and the incidence of PONV was 3 to 4 times lower than in the TIVA, and TIVA patients' groups $(P<0.05)$. In the EA and TAP groups, patients became mobile after 8-13 hours after surgery, in the group TIVA - after 16-22 hours, in the group RSB - after 18-36 hours, in the group TIVA $_{2}$ - after 48-96 hours $(P<0.05) .100 \%$ of the respondents from the EA, TAP and RSB groups were satisfied with the analgesic regimen at the "excellent - good" level. In the TIVA, and TIVA groups, 20-25\% of respondents identified analgesic comfort as "good", 60-65\% of respondents - as "satisfactorily", about $15 \%$ of respondents - as "unsatisfactorily" $(P<0.05)$.

Conclusions. In laparoscopic surgery the use of EA or TAP-block in obese patients significantly reduces the level of postoperative pain, the need for opioids, the incidence of dyspnea and PONV, which leads to the possibility of patients' mobilization within 8-13 hours after surgery. After laparotomic surgery in obese patients RSB effectively "rescues" from pain and prevents excessive use of opioids, which reduces the number of adverse reactions and increases satisfaction with the quality of analgesia.

\section{Ефективність регіонарних технік аналгезії в абдомінальній хірургії в пацієнтів з ожирінням}

\section{С. І. Воротинцев, М. Б. Гриньовська, М. М. Софікканич, О. В. Захарчук}

Використання реґіонарних технік аналгезії в абдомінальній хірургії є важливим компонентом мультимодального підходу до періопераційного знеболення, але дані щодо їх застосування в пацієнтів з ожирінням залишаються обмеженими.

Мета роботи - визначити ефективність епідуральної аналгезії (ЕA) та блоку площини поперечного м'яза живота (ТАР-блоку) під час лапароскопічних операцій у пацієнтів з ожирінням, а також оцінити можливість використання блоку піхви прямого м'яза живота (RSB) як «рятівного» знеболення після лапаротомних операцій у пацієнтів 3 ожирінням.

Матеріали та методи. Проаналізували дані 102 пацієнтів з ожирінням, які оперовані з приводу грижі стравохідного отвору діафрагми, пухлини товстого кишечника, післяопераційної вентральної грижі, морбідного ожиріння та холедохолітіазу. Для періопераційної аналгезії лапароскопічних операцій у 20 пацієнтів використовували ЕА (група ЕА), у 21 пацієнта - ТАР-блок (група ТАР), у 21 пацієнта - опіоїди та нестероїдні протизапальні засоби (НПЗ3) без будь-яких

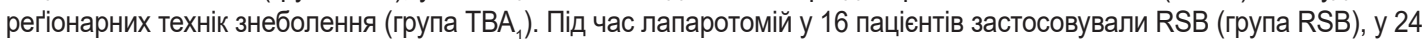
пацієнтів - тількі опіоїди та НПЗ3 (група ТВА ${ }_{2}$ ). Після операції оцінювали час екстубації трахеї, загальну дозу наркотиків, рівень болю за 10-бальною цифровою рейтинговою шкалою (NRS), інцидентність диспное за допомогою монітора Utas 300 (Україна), випадки післяопераційної нудоти та блювоти (PONV), час активної мобілізації пацієнтів та рівень задоволеності аналгетичним режимом. Для групи RSB додатково визначали складність виконання RSB і середній час досягнення адекватної аналгезії (інтенсивність болю $\leq 3$ балів за NRS). Статистичний аналіз виконали за допомогою програми Statistica for Windows version 6.0. 
Результати. У групі ЕА інтраопераційна доза фентанілу була вдвічі меншою, а пацієнти були екстубовані вдвічі швидше, ніж в групах TAP, TBA $1, R S B$, TBA $_{2}(p<0,05)$. Жоден пацієнт із групи ЕА не потребував відновлення нервово-м'язової провідності за допомогою неостигміну $(p<0,05)$. Після операції рівень болю був у $2-3$ рази вищим у групах TBA,,$R S B$, TBA , ніж у групах EA i TAP ( $p<0,05)$. «Рятівне» знеболення у групі RSB виконали з першої спроби в усіх пацієнтів за 5-10 Хв, отримали адекватний ефект через 3 (2-4) хв. Рівень складності RSB визначений як «легко» у 12 (75\%) пацієнтів, як «середньо» у 4 (25 \%) пацієнтів ( $p<0,05)$. Інцидентність диспное та доза опіоїдів після операції в пацієнтів із груп $\mathrm{EA}$, TAP i RSB була вдвічі меншою, а інцидентність PONV в 3-4 рази меншою, ніж у пацієнтів із груп TBA, і TBA $(p<0,05)$. У групах EA і TAP пацієнти стали мобільними через 8-13 годин, у групі TBA 1 - через 16-22 години, в групі RSB - через 18-36 годин, у групі TBA ${ }_{2}$ - через 48-96 годин після операції ( $\left.<<0,05\right)$. 3 груп EA, TAP i RSB 100 \% респондентів були задоволені аналгетичним режимом на рівні «відмінно - добре». У групах ТВА, і ТВА $20-25 \%$ респондентів визначили рівень аналгетичного комфорту як «добре», 60-65 \% - як «задовільно», майже $15 \%$ - як «незадовільно» $(p<0,05)$.

Висновки. У лапароскопічній хірургії в пацієнтів з ожирінням використання ЕА або ТАР-блоку вірогідно знижує рівень післяопераційного болю, необхідність застосування опіоїдів, інцидентність диспное та PONV, що призводить до можливості мобілізації пацієнтів уже через 8-13 годин після операції. Після лапаротомної хірургії в пацієнтів з ожирінням RSB ефрективно «рятує» від болю та запобігає надмірному призначенню опіоїдів, що зменшує кількість побічних реакцій та підвищує задоволеність пацієнтів якістю аналгезії.

Ключевые слова: ожирение, абдоминальная хирургия, анестезия и обезболивание.

Патология. - 2018. T. 15, № 2(43). -

C. 229-235

\section{Эффективность регионарных техник аналгезии в абдоминальной хирургии у пациентов с ожирением}

\section{С. И. Воротынцев, М. Б. Гриновская, М. М. Софияканич, А. В. Захарчук}

Использование регионарных техник аналгезии в абдоминальной хирургии - важный компонент мультимодального подхода к периоперационному обезболиванию, но данные по их применению у пациентов с ожирением остаются ограниченными.

Цель работы - определить эффективность эпидуральной аналгезии (ЭА) и блока плоскости поперечной мышцы живота (ТАР-блока) при лапароскопических операциях у пациентов с ожирением, а также оценить возможность использования блока влагалища прямой мышцы живота (RSB) в качестве «спасательного» обезболивания после лапаротомных операций у пациентов с ожирением.

Материалы и методы. Проанализированы данные 102 пациентов с ожирением, оперированных по поводу грыжи пищеводного отверстия диафрагмы, опухоли толстого кишечника, послеоперационной вентральной грыжи, морбидного ожирения и холедохолитиаза. Для периоперационной аналгезии лапароскопических операций у 20 пациентов использовали ЭА (группа ЭА), у 21 пациента - ТАР-блок (группа ТАР), у 21 пациента - опиоиды и нестероидные противовоспалительные средства (НПВС) без каких-либо регионарных техник аналгезии (группа ТВА ) $_{1}$. При лапаротомии у 16 пациентов применяли RSB (группа RSB), у 24 пациентов - только опиоиды и НПВC (группа TВА 2 ). После операции оценивали время экстубации трахеи, общую дозу наркотиков, уровень боли по 10-балльной цифровой рейтинговой шкале (NRS), инцидентность одышки с помощью монитора Utas 300 (Украина), случаи послеоперационной тошноты и рвоты (PONV), время активной мобилизации пациентов и уровень удовлетворенности аналгетическим режимом. Для группы RSB дополнительно определяли сложность выполнения RSB и среднее время достижения адекватной аналгезии (интенсивность боли $\leq 3$ баллов по NRS). Статистический анализ выполнили с помощью программы Statistica for Windows version 6.0.

Результаты. В группе ЭА интраоперационная доза фентанила была вдвое меньше, а пациенты были екстубированы вдвое быстрее, чем в группах TAP, TBA, RSB, TBA $(p<0,05)$. Ни один пациент из группы ЭА не нуждался в восстановлении нейромышечной проводимости с помощью неостигмина $(p<0,05)$. После операции уровень боли был в 2-3 раза выше в группах TBA, RSB, TBA, чем в группах ЭА и TAP $(p<0,05)$. «Спасательное» обезболивание в группе RSB выполнили с первой попытки у всех пациентов за 5-10 мин, получили адекватный эффект через $3(2-4)$ мин. Уровень сложности RSB определен как «легко» у 12 (75\%) пациентов, как «средне» у $4(25 \%)$ пациентов ( $><0,05)$. Инцидентность одышки и доза опиоидов после операции у пациентов из групп EA, TAP и RSB была в 2 раза меньше, а инцидентность PONV в 3-4 раза меньше, чем у пациентов из групп ТВА и иВА $(p<0,05)$. В группах ЕА и ТАР пациенты стали мобильными через 8-13 часов, в группе TBA - через 16-22 часа, в группе RSB - через 18-36 часов, в группе TВА - через 48-96 часов после операции $(p<0,05)$. В группах EA, TAP и RSB $100 \%$ респондентов были довольны аналгетическим режимом на уровне «отлично - хорошо». В группах ТВА, и ТВА, 20-25\% респондентов определили уровень аналгетического комфорта как «хорошо», 60-65 \% - как «удовлетворительно», около $15 \%$ - как «неудовлетворительно» $(p<0,05)$.

Выводы. В лапароскопической хирургии у пациентов с ожирением использование ЭА или ТАР-блока достоверно снижает уровень послеоперационной боли, необходимость применения опиоидов, инцидентность диспноэ и PONV, что приводит к возможности мобилизации пациентов уже через 8-13 часов после операции. После лапаротомной хирургии у пациентов с ожирением RSB эфффективно «спасает» от боли и предотвращает чрезмерное назначение опиоидов, что уменьшает количество их побочных реакций и повышает удовлетворенность пациентов качеством аналгезии.

\section{Background}

Laparoscopy is the best surgical technique for colorectal and bariatric surgery, cholecystectomy, appendectomy, antireflux and ventral hernia operations [1]. It is incorporated into the enhanced recovery protocol (ERAS) for intestinal and bariatric surgery [2,3]. It has been proven that compared with open resection of the bowel, laparoscopy leads to rapid recovery of its function, reduction of intraoperative blood loss, decrease in postoperative pain intensity and the need for opioids, reduction of overall morbidity and length of hospital stay, improved short-term 
quality of life [4]. In the bariatric surgery, the laparoscopy significantly reduces the length of hospital stay, reduces blood loss and the level of postoperative pain, leads to an earlier recovery $[1,5]$.

Although laparoscopy is a less invasive technique, modern approach to perioperative analgesia should be based on the multimodal principle, when drugs with different mechanisms of action are used along with opioids, resulting in additional and/or synergistic effect on analgesia [6]. These drugs include a2-agonists, NMDA-receptor antagonists, gabapentinides, dexamethasone, non-steroidal anti-inflammatory drugs (NSAIDs), acetaminophen, and others. Combined use of various analgesics can reduce the total dose of opioids and speed up the recovery time after surgery. In patients with obesity such principle which underlies opioid-free anesthesia (OFA), when, according to Jan P.Mulier, one jointly uses: a) drugs that directly (clonidine, dexmedetomidin, $\beta$-blokers) or indirectly (nicardipine, lidocaine, $\mathrm{MgSO}_{4}$, inhaled anesthetics) block the sympathetic nervous system; b) non-opiod analgesics (small doses of ketamine, dexmedetomidine, lidocaine, diclofenac, paracetamol), which are administered intraoperatively to obtain a peak of their activity after awakening; c) neuroaxial anesthesia techniques and regional blockades [7].

The use of regional analgesia in abdominal surgery has long been proposed by experts from the PROSPECT group but in case of laparoscopy, infiltration of tissues and peripheral nerve blockades are more beneficial than neuroaxial blockades [8]. At present blockade of transverse abdominal muscle plane (TAP-block) is a good alternative to epidural analgesia (EA), and some authors even suggest it's a "gold standard" for postoperative analgesia in abdominal surgery [9]. But in case of transition to conversion due to the complexity or inability to perform laparoscopy in obese patients, TAP-block is not always the best option due to technical difficulties with ultrasound (US) visualisation of lateral abdominal wall and risk of anesthetic overdose through introduction of large volumes of solution. A simpler, safer and more effective method is the bilateral double blockage of the rectus muscle sheath (RSB), which is increasingly used for intra- [10] and postoperative analgesia of laparotomic wounds [11], but not for obese patients.

Obviously adequate analgesia after midline laparotomy is ensured by opioids, especially effective in addressing the visceral component of pain. However, their side effects such as gastrointestinal dysfunction, ileus and constipation, are major issues that may delay recovery after surgery [12]. In addition, the administration of opioids may contribute to hypoventilation and hypoxemia in the postoperative period in obese patients [7]. Therefore, based on the principles of OFA, we believe that the additional use of regional techniques such as EA, TAP-block and RSB in abdominal surgery patients with obesity has advantages over "standard" analgesia by opioids and NSAIDs.

\section{Aim}

To determine the effectiveness of EA and TAP-block in different laparoscopic operations in patient with obesity and to evaluate the possibility of using double bilateral RSB as "rescue" analgesia after laparotomy in obese patients.

\section{Materials and methods}

After approval of the committee on bioethics in Zaporizhzhya State Medical University and obtaining written informed consent, patients with a body mass index (BMI) over $30 \mathrm{~kg} / \mathrm{m}^{2}$, functional class ASA I to III and aged over 18 years have been consistently included in the study. To determine the effectiveness of EA and TAP-block, study groups included patients scheduled for laparoscopic surgery with the following exclusion criteria: the transition from laparoscopy to laparotomy, reoperations in the immediate postoperative period or withdrawal of patient at any stage of the study. To determine the effectiveness of RSB, study groups included laparotomy patients with no use of regional anesthesia techniques during surgery, with the following exclusion criteria: presence of peripheral neuropathy, severe heart disease, contraindications to regional anesthesia and known allergic reactions to local anesthetics. All the patients had a total intravenous anesthesia (TIVA) on the basis of propofol, fentanyl and atracurium without the use of local infiltration of the surgical site. Dosage was determined by clinical signs of the depth of anesthesia and myoplegia. As a component of multimodal analgesia intraoperatively ketamine was applied $0.15 \mathrm{mg} / \mathrm{kg}$ of ideal body weight (IBW) per hour (intravenous bolus) and clonidine for a total dose of 100 mcg in all patients.

Allocation of study groups was performed with the use of sealed envelopes before the start of anesthesia. In the EA group the epidural administration of a local anesthetic was used for the perioperative analgesia according to the procedure described earlier [13]. In the TAP group, after the end of the surgery until the extubation, a classic percutaneous bilateral blockade of the transverse abdominal muscle plane was performed with the control of ultrasound [14]. In the RSB and TVA groups, no regional anesthesia techniques were involved during surgery, only "standard" analgesia with the use of opioids. After regaining consciousness, all patients were extubated in the operating room and transferred to postoperative ward where the level of pain was assessed according to a numeric rating scale (NRS) from 0 (no pain) to 10 (maximum pain) and incidence of dyspnea was monitored in the first two hours after surgery, according to the saturation and capnometry values measured with the monitor UM-300 (UTAS, Ukraine). There have been also documented cases of postoperative nausea and vomiting (PONV). Standard analgesia included NSAIDs (diclofenac $150 \mathrm{mg}$ / day) and, if necessary (NRS $>3$ points), anesthesist-controlled analgesia (ACA) with the use of trimeperidine. In the RSB group, with a NRS value of more than 3 points, as a "rescue" analgesia, a bilateral double blockage of the rectus abdominal muscle sheath was used. The RSB was performed with the help of an ultrasound scanner Logiq $\mathrm{e}$ (GE, USA) and a linear (8-12 MHz) or convective (4.5-6.5 $\mathrm{MHz}$ ) probes, depending on the quality of the visualization of the required anatomical structures. Applying the technique of "4 quadrants" when bilaterial double single injections of anesthetic performed at the border between 
$1 / 4$ and $3 / 4$ of the distance to the upper and lower ends of the wound. After transverse positioning of the probe on the anterior abdominal wall in the above areas, it was displaced laterally to obtain a good visualization of the rectus muscle of the abdomen and the lateral part of its sheath. With the help of in-plane technique, the tip of the spinal needle $G 22$ had to be inserted into the space between the hypoechoic rectus muscle and its hyperechoic posterior sheath. After a negative aspiration test, $1 \mathrm{ml}$ of $1 \%$ solution of lidocaine and $0.25 \%$ bupivacaine solution was injected to confirm the correct position of the needle tip. A further injection of $9 \mathrm{ml}$ in the correct plane created a visible pool of anesthetic solution that separated the rectus muscle from its sheath. Thus, the total volume of anesthetic solution was $40 \mathrm{ml}$ for all the patients, which corresponded to a safe dosage of both lidocaine $(400 \mathrm{mg})$ and bupivacaine $(100 \mathrm{mg})$.

The endpoints of the study were: the time of the tracheal extubation after the surgery, the total intraoperative dose of fentanyl, the total dose of trimeperidine in the first 24 hours after the surgery, the mobilization time (ability to move independently). In the RSB group the complexity of the procedure was further determined, according to indicators such as the time for its implementation, the number of attempts and complications that were measured and recorded on the basis of a subjective ranking on a fourpoint scale (1 - easy, 2 - medium, 3 - difficult, 4 - very difficult). The average time to achieve an adequate block was fixed when the patient noted a decrease in pain intensity to $\leq 3$ points for the NRS and could breathe freely and deeply. Before discharge from the hospital, in patients of all the groups the degree of general comfort from the received analgesic regimen was evaluated according to the following numerical scale: 4 (excellent) - without pain; 3 (good) - slight pain without the need for additional analgesics; 2 (satisfactory) - a pain that required additional analgesics; 1 (bad) - pain that did not diminish after prescription of additional analgesics.

The statistical analysis was performed using the Statistica for Windows version 6.0 software (StatSoft Inc., USA, series number AXXR712D833214FAN5). Quantitative variables are presented as mean \pm standard deviation with normal data distribution, median and quartile - when allocating data were different from normal distribution. For comparison, Student's t-test and Mann-Whitney $U$-test were used. Categorical variables were calculated as frequencies and compared with the criterion $X^{2}$ or Fisher's exact test. Differences with a value of $P<0.05$ were considered statistically significant.

\section{Results}

In total 102 patients with different pathology of the gastrointestinal tract (GIT) and the anterior abdominal wall have been studied. 62 laparoscopy patients were allocated in the EA $(n=20), \operatorname{TAP}(n=21)$ and $\operatorname{TIVA}_{1}(n=21)$ groups. 40 laparotomy patients were allocated in $\operatorname{RSB}(n=16)$ and TIVA $_{2}(n=24)$ groups. According to demographic indicators, functional status for ASA and BMI groups did not have statistically significant differences (Table 1).

As can be seen from Table 1, the majority of patients in the "laparoscopic" part of the study were operated on a hernia of the esophageal hiatus of diaphragm (52-61\%) and colon tumors (19-24\%). The minimum number of these was made up of patients undergoing a sleeve resection of the stomach $(10 \%)$ or transabdominal hernioplasty (10-14 \%). On the contrary, in the "laparotomy" part of the study, significantly more patients were operated on anterior abdominal hernia (50-56 \%) and choledocholithiasis (29\%), significantly fewer patients had fundoplplication (19\%), and open Sleeve-resection was not performed at all $(P<0.05)$. In the RSB group, there were no patients after open cholelithiasis, but it included 3 patients after laparotomy fundoplication. We considered it possible for them to be included for comparison, since these operations used the same surgical access - upper middle line laparotomy.

The average duration of surgery was almost 1.5 times longer in patients with laparotomy $(P<0.05)$. However, only in the EA group, the dosage of fentanyl and atracurium was on average twice less than in other groups $(P<$ 0.05 ), clearly confirming the opioid-sparing and "relaxing" effect of the epidural component of analgesia, regardless of the technique of surgical intervention. Probably, this contributed to an earlier tracheal extubation of patients in the EA group compared to patients from the TAP, TIVA, RSB and TIVA ${ }_{2}$ groups $(P<0.05)$. It should also be noted that in the EA group, no patient needed restoration of neuromuscular conduction with neostigmine, but in other groups it was administered to all the patients $(P<0.05)$.

The evaluation of postoperative pain showed that its level 1 hour after surgery was higher in the groups where the regional techniques of analgesia $\left(\right.$ TIVA $_{1}, \mathrm{RSB}, \mathrm{TIVA}_{2}$ ) were not used $(P<0.05)$, requiring the use of "rescue" pain treatment in $2 / 3$ patients of these groups (Table 2). However, if tremeperidine was administered in the TIVA, and TIVA ${ }_{2}$ groups, the bilateral RSB was performed in the RSB group: in the $14(87.5 \%)$ patients a linear probe was used, since the depth of the rectus muscle sheath was not more than $5 \mathrm{~cm}$; in $2(12.5 \%)$ patients with $\mathrm{BMI}>45$ $\mathrm{kg} / \mathrm{m}^{2}$, a convective probe was used, since the distance between the skin and the target was more than $6 \mathrm{~cm}$. All blockades were performed on the first attempt, their total duration was 5-10 minutes (1.5-2.0 minutes per one injection), the complexity of the performance was assessed as "easy" in 12 (75\%) patients, "moderate" - in 4 (25\%) patients $(P<0.05)$. The average time to achieve adequate analgesia was $3(2-4)$ min after the completion of the blockade. In 1 (6\%) patient, the RSB was inadequate and trimeperidine was additionally administered. No RSB complications were detected.

Due to the use of regional analgesia techniques, patients in the EA, TAP and RSB groups had a 2-fold lower incidence of dyspnea in the first 2 hours after surgery than patients in the TIVA $A_{1}$ and TIVA ${ }_{2}$ groups $(P$ $<0.05$ ). For the same reason, the overall consumption of trimeperidine was twice less in the EA, TAP and RSB groups than in the TIVA $A_{1}$ and TIVA $_{2}$ groups ( $P$ $<0.05$ ), suggesting probably three to four times less the incidence of PONV in these groups, in compared with groups where regional analgesia was not used $(P$ $<0.05)$. The abovementioned resulted in the fact that laparoscopy patients from groups EA and TAP began to move independently in the ward after 8-13 hours after 
Table 1. Patient Characteristics

\begin{tabular}{|c|c|c|c|c|c|}
\hline \multirow[t]{3}{*}{ Value } & \multicolumn{5}{|c|}{ Surgery and analgesia technique } \\
\hline & \multicolumn{3}{|c|}{ Laparoscopy } & \multicolumn{2}{|l|}{ Laparotomy } \\
\hline & $E A(n=20)$ & $\operatorname{TAP}(n=21)$ & $\mathrm{TBA}_{1}(\mathrm{n}=21)$ & RSB $(n=16)$ & $\mathrm{TBA}_{2}(n=24)$ \\
\hline Age, years & $52.6 \pm 10.3$ & $54.2 \pm 11.7$ & $53.3 \pm 10.6$ & $55.1 \pm 10.7$ & $53.8 \pm 12.2$ \\
\hline Sex, male/female, $n$ & $6 / 14$ & $6 / 15$ & $5 / 16$ & $6 / 10$ & $9 / 15$ \\
\hline ASA $1 / I / / I I, n$ & $5 / 13 / 2$ & $4 / 15 / 2$ & $5 / 15 / 1$ & $2 / 8 / 8$ & $3 / 11 / 10$ \\
\hline $\mathrm{BMI}, \mathrm{kg} / \mathrm{m}^{2}$ & $36.1 \pm 5.2$ & $34.4 \pm 4.5$ & $35.6 \pm 5.3$ & $35.2 \pm 5.5$ & $36.7 \pm 6.1$ \\
\hline \multicolumn{6}{|l|}{ Kind of surgery: } \\
\hline Fundoplication, $\mathrm{n}(\%)$ & $12(60)$ & $11(52)$ & $13(61)$ & $3(19)$ * & $-*$ \\
\hline Hemicolectomy, n (\%) & $4(20)$ & $5(24)$ & $4(19)$ & $4(25)$ & $5(20.8)$ \\
\hline Sleeve-resection, n (\%) & $2(10)$ & $2(10)$ & $2(10)$ & - & - \\
\hline Choledochotomy, n (\%) & - & - & - & - & $7(29.2)^{*}$ \\
\hline Hernioplasty, n (\%) & $2(10)$ & $3(14)$ & $2(10)$ & $9(56)^{*}$ & $12(50)^{*}$ \\
\hline Surgery duration, min. & $115(98-133)$ & $124(110-137)$ & $110(93-128)$ & $156(116-172)^{*}$ & $155(125-168)$ * \\
\hline \multicolumn{6}{|l|}{ I/op medication: } \\
\hline Fentanyl, mg & $0.6(0.5-0.8)^{\#}$ & $1.2(1.0-1.4)$ & $1.2(1.0-1.3)$ & $1.3(1.0-1.4)$ & $1.4(1.1-1.5)$ \\
\hline Atracurium, mg & $55(40-60)^{\#}$ & $100(80-110)$ & $90(70-110)$ & $130(110-150)$ & $140(120-150)$ \\
\hline Neostigmine, mg & $-\#$ & $0.8(0.5-1.0)$ & $0.9(0.5-1.0)$ & $0.8(0.7-1.1)$ & $1.0(0.6-1.2)$ \\
\hline Time of extubation, min. & $15(10-17)^{\#}$ & $30(20-45)$ & $25(20-35)$ & $30(25-35)$ & $35(20-45)$ \\
\hline
\end{tabular}

ASA: American Society of Anesthesiologists; BMI: body mass index; Sleeve-resection: stomach resection; i/op: intraoperative; *: P < 0.05 laparotomy vs laparoscopy; $\#: \mathrm{P}<0.05$ EA group vs other groups.

Table 2. Postoperative analgesia quality values

\begin{tabular}{|c|c|c|c|c|c|}
\hline Value & $E A(n=20)$ & $\operatorname{TAP}(n=21)$ & $\mathrm{TBA}_{1}(\mathrm{n}=21)$ & $\operatorname{RSB}(n=16)$ & $\mathrm{TBA}_{2}(\mathrm{n}=24)$ \\
\hline NRS, scores & $1(0-1)$ & $2(0-3)$ & $3(2-5)^{\#}$ & $5(4-7)^{\star}$ & $5(4-6)^{\star}$ \\
\hline «Rescue» analgesia $60 \mathrm{~min}, \mathrm{n}(\%)$ & - & - & $15(71)^{\#}$ & $12(75)^{\star}$ & $17(71)^{\star}$ \\
\hline Dyspnea, $\mathrm{n} / 2$ hours & $4(2-7)$ & $6(4-7)$ & $10(5-12)^{\#}$ & $5(3-7)$ & $11(6-13)^{\#}$ \\
\hline Nausea, $\mathrm{n}(\%)$ & $2(10)$ & $3(14)$ & $7(33)^{\#}$ & $3(18.7)$ & $12(50)^{\#}$ \\
\hline Vomiting, $\mathrm{n}(\%)$ & $1(5)$ & $1(5)$ & $3(7)^{\#}$ & $0(0)$ & $4(9)^{\#}$ \\
\hline Trimeperidine, $\mathrm{mg} / 24$ hours & $20(0-20)$ & $20(0-40)$ & $40(20-60)^{\#}$ & $30(20-40)$ & $60(40-80)^{\#}$ \\
\hline Mobilisation, hours & $10(8-12)$ & $11(10-13)$ & $18(16-22)^{\#}$ & $24(18-36)$ & $72(48-96)^{*}$ \\
\hline
\end{tabular}

*: $P<0.05$ laparotomy vs laparoscopy; *: $P<0.05$ TBA $_{1}$ and TBA $\mathrm{A}_{2}$ groups vs EA, TAP, RSB groups.

surgery, whereas patients from the group TIVA $_{1}$ - only on the next day $(P<0.05)$. Laparotomy patients from the RSB group have been activated since the end of the $1^{\text {st }}$ day after surgery, while patients from the TIVA group - only 72 hours after the operation $(P<0.05)$.

Analysis of the patients' assessment of the quality of analgesia showed that it was significantly higher in the EA, TAP and RSB groups, where $100 \%$ of the respondents reported satisfaction at the "excellent-good" level. In the TIVA, and TIVA, groups, only $20-25 \%$ of respondents identified comfort levels as "good", 60-65\% of respondents - as "satisfactorily", and about $15 \%$ of respondents - were dissatisfied with postoperative analgesia $(P<0.05)$.

\section{Discussion}

The pain after laparoscopic surgery has two components: visceral and somatic. The visceral component is associated with surgical intervention, tissue damage and stretching of the nerve endings. Pneumoperitoneum leads to stretching of the peritoneum and diaphragmatic muscle fibers, which irritates the phrenicus nerve. Since this nerve shares the general path with nerves that innervate the shoulder, its irritation can lead to shoulder pain. The somatic component of the pain is associated with the apertures made in the abdominal wall for the entry of the trocar. Kim S. B. et al. [15] proved that somatic pain after laparoscopic cholecystectomy predominates over visceral pain. Therefore, the multimodal approach with the use of various regional analgesia techniques in laparoscopic surgery can contribute to the improvement of the quality of perioperative analgesia, thus preventing the development of side effects associated with the use of opioids. This is of paramount importance in obese patients because they are particularly susceptible to sedative and respiratory-depressive effects of opioids.

In bariatric surgery, epidural analgesia and infiltration of the port areas by local anesthetic show a reduction in postoperative pain compared with an exclusive intravenous patient-controlled analgesia [16]. In case of Sleeve-resection Sinha et al. [17], Wassef et al. [18] use the TAP-block as part of a multimodal analgesic technique, proving its qualitative analgesic efficacy with reduced airway complications and PONV cases. In our study, patients in the EA group received both reduction in the dose of fentanyl intraoperatively and reduction in the total dosage of trimeperidine after the surgery, which limited the incidence of such side effects of opioids as dyspnea and PONV. The TAP group also noted the positive effect of this technique on the quality of postoperative analgesia. Thus, more effective analgesia allowed to accelerate the time of mobilization of patients with EA or TAP block up to 8-13 hours after surgery, whereas in patients without 
regional analgesia techniques this index was 18 (16-22) hours $(P<0.05)$. In our opinion, the only deterrent factor in the use of EA and TAP-block in laparoscopic surgery in obese patients is the difficulty in performing these techniques due to the absence of clear anatomical landmarks. But this issue is well resolved with the help of ultrasonic navigation, which allows you to perform manipulation with $100 \%$ success.

The blockage of the rectus muscle sheath (RSB) is used to provide somatic analgesia in middle line segments in laparoscopic and laparotomic surgery. With hernioplasty of umbilical hernia, RSB shows an effective analgesia in both children [19] and in selected adult patients [20]. But the greatest potential benefit of RSB may be the guaranteed anesthetizing of the anterior abdominal wall after "large" laparotomic surgery. Thus, two recent retrospective studies show that in patients undergoing colorectal surgery, bilateral double RSB may be as effective as EA but with less side effects [21,22].

Based on the potential benefits of RSB for treating somatic pain from laparotomy, we examined the feasibility of using it as a method of "rescue" analgesia in patients with obesity after open abdominal surgery. It turned out that the RSB was relatively easy to perform with ultrasound and to achieve effective analgesia in a few minutes in most (94\%) patients when administering a mixture of lidocaine and bupivacaine. Even the once-executed RSB allowed us to halve the daily intake of trimeperine and to accelerate significantly the mobilization of laparotomy patients with obesity. These RSB benefits are very useful for ERAS programs and, therefore, are increasingly attracting researchers [23].

An audit of patient satisfaction with the analgesia mode confirmed our opinion on the feasibility of mandatory use of regional analgesia techniques in laparotomic and laparoscopic surgery in obese patients, since it provided objective information about their effectiveness, simplicity and safety. In addition, we believe that RSB is a promising method of analgesia for widespread use in such patients with an unplanned transition to conversion, unless neuraxial analgesia is used.

\section{Conclusions}

In laparoscopic surgery the use of EA or TAP-block significantly reduces the level of postoperative pain, the need for opioids, the incidence of dyspnea and PONV, which leads to the possibility of patients' mobilization within 8-13 hours after surgery. After laparotomy in obese patients RSB effectively "rescues" from pain and prevents excessive use of opioids, reduces the number of their adverse reactions and increases the satisfaction of patients with the quality of anesthesia.

Conflicts of Interest: authors have no conflict of interest to declare. Конфлікт інтересів: віАсутній.

Information about authors:

Vorotyntsev S. I., MD, PhD, Associate Professor,

Department of Surgery and Anesthesiology of Postgraduate

Education Faculty, Zaporizhzhia State Medical University,

Ukraine.
Hrynovska M. B., MD, Assistant Professor, Department of Anesthesiology and Intensive Care, Ivano-Frankivsk National Medical University, Ukraine.

Sofilkanych M. M., MD, PhD, Assistant Professor, Department of Faculty Surgery, Zaporizhzhia State Medical University, Ukraine.

Zakharchuk O. V., MD, PhD, Assistant Professor, Department of Faculty Surgery, Zaporizhzhia State Medical University, Ukraine.

\section{Відомості про авторів:}

Воротинцев С. І., канА. меА. наук, Аоцент каф. хірургії та анестезіології факультету післядипломної освіти, Запорізький Аержавний меАичний університет, Україна.

Гриньовська М. Б., асистент кафедри анестезіології та інтенсивної терапії, Івано-Франківський національний медичний університет, Україна.

Софілканич М. М., канА. меА. наук, асистент каф. факультетської хірургії, Запорізький Аержавний медичний університет, Україна. Захарчук О. В., канА. меА. наук, асистент каф. факультетської хірургії, Запорізький державний медичний університет, Україна.

\section{Сведения об авторах:}

Воротынцев С. И., канА. меА. наук, Аоцент каф. хирургии и анестезиологии факультета последипломного образования, Запорожский государственный медицинский университет, Украина.

Гриновская М. Б., ассистент каф. анестезиологии и интенсивной терапии, Ивано-Франковский национальный меАицинский университет, Украина.

Софилканич М. М., канА. меА. наук, ассистент каф. факультетской хирургии, Запорожский государственный меАицинский университет, Украина.

Захарчук О. В., канА. меА. наук, ассистент каф. факультетской хирургии, Запорожский государственный медицинский университет, Украина.

Надійшла Ао редакції / Received: 03.07.2018

Після Аоопрацювання / Revised: 11.08.2018

Прийнято Ао Аруку / Accepted: 20.08.2018

\section{References}

[1] Nguyen, N. T., Nguyen, B., Shih, A., \& Smith, B. (2013) Use of laparoscopy in general surgical operations at academic centers. Surgery for Obesity and Related Diseases, 9(1), 15-20. doi: 10.1016/j. soard.2012.07.002

[2] Carmichael, J. C., Keller, D. S., Baldini, G., Bordeianou, L., Weiss, E., Lee, L., et al. (2017) Clinical Practice Guidelines for Enhanced Recovery After Colon and Rectal Surgery From the American Society of Colon and Rectal Surgeons and Society of American Gastrointestinal and Endoscopic Surgeons. Dis Colon Rectum., 60(8), 761-784. doi: 10.1097/ DCR. 0000000000000883.

[3] Thorell, A., MacCormick, A. D., Awad, S., Reynolds, N., Roulin, D., Demartines, N., et al. (2016) Guidelines for Perioperative Care in Bariatric Surgery: Enhanced Recovery After Surgery (ERAS) Society Recommendations. World J Surg, 40(9), 2065-83. doi: 10.1007/ s00268-016-3492-3.

[4] Yamamoto, S., Inomata, M., Katayama, H., Mizusawa, J., Etoh, T., Konishi, F., et al. (2014) Short-term surgical outcomes from a randomized controlled trial to evaluate laparoscopic and open D3 dissection for stage II/III colon cancer. Ann Surg, 260(1), 23-30. doi: 10.1097/ SLA.0000000000000499.

[5] Reoch, J., Mottillo, S., Shimony, A., Filion, K. B., Christou, N. V., Joseph, L., et al. (2011) Safety of Laparoscopic vs Open Bariatric Surgery. A Systematic Review and Meta-analysis. Arch Surg, 146(11), 1314-22. doi: 10.1001/archsurg.2011.270.

[6] Helander, E. M., Menard, B. L., Harmon, C. M., Homra, B. K., Allain, A. V., Bordelon, G. J., et al. (2017) Multimodal Analgesia, Current Concepts, and Acute Pain Considerations. Curr Pain Headache Rep., 21(1), 3. doi: 10.1007/s11916-017-0607-y.

[7] Mulier, J. P. (2016) Perioperative opioids aggravate obstructive breathing in sleep apnea syndrome: mechanisms and alternative anaesthesia strategies. Curr Opin Anaesthesiol., 29(1), 129-33. doi: 10.1097। ACO.0000000000000281.

[8] http://www.postoppain.org 
[9] Fiorini, F., Sessa, F., Congedo, E., \& Cosmo, G. D. (2016) Transversus Abdominis Plane Block: A New Gold Standard for Abdominal Surgery? J Anesth Crit Care Open Access., 4(3), 00145. doi: 10.15406/ jaccoa.2016.04.00145.

[10] Quek, K. H. Y., \& Phua, D. S. K. (2014) Bilateral rectus sheath block as the single anaesthetic technique for an open infraumbilical hernia repair. Singapore Med J., 55(3), e39-e41. doi: 10.11622/smedj.2014042.

[11] Yassin, H. M., Elmoneim, A. T. A., \& Moutaz, H. E. (2017) The Analgesic Efficiency of Ultrasound-Guided Rectus Sheath Analgesia Compared with Low Thoracic Epidural Analgesia After Elective Abdominal Surgery with a Midline Incision: A Prospective Randomized Controlled Trial. Anesth Pain Med., 7(3), e14244. doi: 10.5812/aapm.14244.

[12] Beard, T. L.,Leslie, J. B. \& Nemeth, J. (2011) The opioid component of delayed gastrointestinal recovery after bowel resection. J Gastrointest Surg., 15(7), 1259-68. doi: 10.1007/s11605-011-1500-3.

[13] Vorotyntsev, S., Grytcenko, S., \& Grynovska, M. Multimodal Anesthesia/Analgesia Model In Obese Patients Undergoing Open Abdominal Surgery. GSL Journal of Anesthesiology. Retrieved from http://gslpublishers.org/journals/current-issue.php?title=gsl-journal-of-anesthesiology-open-access\#journals/article.php?title $=$.

[14] Vorotyntsev, S. I., Sofylkanich, M. M., \& Zakharchuk, O. V. (2017) The plane blockade of transversal abdominal muscle after laparoscopic resection of large bowel in patients, suffering obesity. Klinicheskaia khirurgiia, 6, 21-24.

[15] Kim, S. B., Lee, I. O., Kong, M. H., Lee, M. K., Kim, N. S., Choi, Y. S., \& Lim, S. H. (2001) Pain after laparoscopic cholecystectomy: comparison between somatic pain and visceral pain. Korean J Anesthesiol., 41, 66-70. doi: 10.4097/kjae.2001.41.1.66.

[16] Ruiz-Tovar, J., Muñoz, J. L., Gonzalez, J., Zubiaga, L., García, A., Jimenez, M., Ferrigni, C., \& Durán, M. (2017) Postoperative pain after laparoscopic sleeve gastrectomy: comparison of three analgesic schemes (isolated intravenous analgesia, epidural analgesia associated with intravenous analgesia and port-sites infiltration with bupivacaine associated with intravenous analgesia). Surg Endosc., 31(1), 231-236. doi: 10.1007/s00464-016-4961-3.

[17] Sinha, A., Jayaraman, L., \& Punhani, D. (2013) Efficacy of ultrasound-guided transversus abdominis plane block after laparoscopic bariatric surgery: a double blind, randomized, controlled study. Obes Surg., 23(4), 548-553. doi: 10.1007/s11695-012-0819-5.

[18] Wassef, M., Lee, D. Y., Levine, J. L., Ross, R. E., Guend, H., Vandepitte, C., et al. (2013) Feasibility and analgesic efficacy of the transversus abdominis plane block after single-port laparoscopy in patients having bariatric surgery. J Pain Res., 6, 837-841. doi: 10.2147/ JPR.S50561.

[19] Willschke, H., Bosenberg, A., Marhofer, P., Johnston, S., Kettner, S. C., Wanzel, O., \& Kapral, S. (2006) Ultrasonography-guided rectus sheath block in paediatric anaesthesia - a new approach to an old technique. Br J Anaesth., 97(2), 244-9. doi: 10.1093/bja/ael143.

[20] Quek, K. H. Y., \& Phua, D. S. K. (2014) Bilateral rectus sheath block as the single anaesthetic technique for an open infraumbilical hernia repair. Singapore Med J., 55(3), e39-e41. doi: 10.11622/smedj.2014042.

[21] Godden, A. R., Marshall, M. J., Grice, A. S., \& Daniels, I. R. (2013) Ultrasonography guided rectus sheath catheters versus epidural analgesia for open colorectal cancer surgery in a single centre. Ann R Coll Surg Engl., 95(8), 591-4. doi: 10.1308/003588413X13629960049270.

[22] Tudor, E., Yang, W., Brown, R., \& Mackey, P. M. (2015) Rectus sheath catheters provide equivalent analgesia to epidurals following laparotomy for colorectal surgery. Ann R Coll Surg Engl., 97(7), 530-3. doi: 10.1308/ rcsann.2015.0018.

[23] Wilkinson, K. M., Krige, A., Brearley, S. G., Lane, S., Scott, M., Gordon, A. C., \& Carlson, G. L. (2014) Thoracic Epidural analgesia versus Rectus Sheath Catheters for open midline incisions in major abdominal surgery within an enhanced recovery programme (TERSC): study protocol for a randomised controlled trial. Trials. 15, 400. doi: 10.1186/1745-6215-15-400. 